\title{
Acoustic analysis of swallowing sounds with the use of Sonar Doppler in premature babies during food transition
}

Análise acústica dos sons da deglutição com o uso do Sonar Doppler em bebês prematuros durante a transição alimentar

Análisis acústico de los sonidos de la deglución con el uso de Sonar Doppler en bebés prematuros

\author{
durante la transición alimentaria
}

Received: 12/30/2021 | Reviewed: 01/04/2022 | Accept: 01/12/2022| Published: 01/14/2022

\author{
Talita Todeschini Vieira \\ ORCID: https://orcid.org/0000-0002-6638-9114 \\ Tuiuti University of Paraná, Brazil \\ E-mail: talitodeschini@gmail.com \\ Ana Clara Gonçalves de Figueiredo \\ ORCID: https://orcid.org/0000-0003-4154-9991 \\ Tuiuti University of Paraná, Brazil \\ E-mail: figueiredo.anaclarag@gmail.com \\ Raquel Guidotti Lemos \\ ORCID: https://orcid.org/0000-0002-5324-0716 \\ Tuiuti University of Paraná, Brazil \\ E-mail: rosane.santos2@utp.br \\ Karina de Fátima Portela de Oliveira Pereira \\ ORCID: https://orcid.org/0000-0001-5626-8020 \\ Tuiuti University of Paraná, Brazil \\ E-mail:kari.portela@gmail.com \\ Bianca Simone Zeigelboim \\ ORCID: https://orcid.org/0000-0003-4871-2683 \\ Tuiuti University of Paraná, Brazil \\ E-mail: bianca.zeigelboim@utp.br \\ José Stechman Neto \\ ORCID: https://orcid.org/0000-0002-0259-2420 \\ Tuiuti University of Paraná, Brazil \\ E-mail: jose.stechmann@utp.br \\ Rosane Sampaio Santos \\ ORCID: https://orcid.org/0000-0001-6400-5706 \\ Tuiuti University of Paraná, Brazil \\ E-mail: rosane.santos2@utp.br
}

\begin{abstract}
Objective: To define the acoustic parameters and the feasibility of using swallowing acoustic analysis as an auxiliary method for the transition from nasogastric or orogastric tube feeding to oral breastfeeding. Methodology: A cross-sectional study, which consisted of the following steps: 1 . Data collection: Thirty-two newborns participated in this study (16 preterm and 16 full-term); 2. Clinical speech-language pathology evaluation: Clinical data were collected using Sonar Doppler used to assess the readiness of preterm infants to start oral feeding and swallowing sounds. Swallowing sounds were captured during breastfeeding and analyzed according to the frequency, intensity, and time of swallowing, as well as the pause time between swallows and the number of swallows. Results: The control and study groups presented significant differences in the mean wave time and swallowing per minute variables. Conclusion: Sonar Doppler, as an instrument used to capture sounds, is a viable auxiliary resource to evaluate the transition from nasogastric or orogastric tube to oral breastfeeding.

Keywords: Infant, premature; Breastfeeding; Doppler effect; Feeding behavior.
\end{abstract}

\section{Resumo}

Objetivo: Definir os parâmetros acústicos e a viabilidade de utilizar a análise acústica da deglutição como um método auxiliar para a transição da alimentação por sonda nasogástrica ou orogástrica para a amamentação oral. Metodologia: Um 
estudo transversal, que consistiu nos seguintes passos: 1. Coleta de dados: Trinta e dois recém-nascidos participaram deste estudo (16 pré-termo e 16 a termo); 2. avaliação clínica fonoaudiológica: Os dados clínicos foram coletados usando Sonar Doppler utilizado a fim de avaliar a prontidão dos bebês prematuros para iniciar a alimentação oral e os sons de deglutição. Os sons de deglutição foram capturados durante a amamentação e analisados de acordo com a frequência, intensidade e tempo de deglutição, assim como o tempo de pausa entre as deglutições e o número de deglutições. Resultados: Os grupos controle e os grupos de estudo apresentaram diferenças significativas no tempo médio das ondas e nas variáveis de deglutição por minuto. Conclusão: O Sonar Doppler, como instrumento utilizado para captar sons, é um recurso auxiliar viável para avaliar a transição da sonda nasogástrica ou orogástrica para a amamentação oral.

Palavras-chave: Recém-nascido prematuro; Aleitamento materno; Efeito Doppler; Comportamento alimentar.

\section{Resumen}

Objetivo: Definir los parámetros acústicos y la viabilidad del uso del análisis acústico de la deglución como método auxiliar para la transición de la alimentación por sonda nasogástrica o orogástrica a la lactancia oral. Metodología: Estudio transversal que consta de los siguientes pasos: 1 . Recogida de datos: Treinta y dos recién nacidos participaron en este estudio (16 pretérmino y 16 a término); 2. Evaluación clínica fonoaudiológica: Se recogieron datos clínicos mediante el sonar Doppler utilizado para evaluar la disposición de los recién nacidos pretérmino a iniciar la alimentación oral y los sonidos de deglución. Se capturaron los sonidos de la deglución durante la lactancia y se analizaron según la frecuencia, la intensidad y el tiempo de deglución, así como el tiempo de pausa entre las degluciones y el número de éstas. Resultados: Los grupos de control y de estudio mostraron diferencias significativas en las variables de tiempo de onda media y deglución por minuto. Conclusión: El Doppler sonar, como instrumento de captación de sonidos, es un recurso auxiliar viable para evaluar la transición de la sonda nasogástrica u orogástrica a la lactancia oral.

Palabras clave: Recien nacido prematuro; Lactancia; Efecto Doppler; Comportamiento alimentario.

\section{Introduction}

The growth and development of preterm or premature infants require specialized care due to anatomic-physiological underdevelopment and difficulties in adapting to extrauterine life (Klock \& Akacoque, 2012). Premature infants are fed by orogastric or nasogastric tubes. After acquiring physiological stability begins the food transition process. Some authors find that $30 \%$ of premature infants have difficulty in the transition process from nasoenteral to oral feeding (Hawdon et al., 2000).

The subjectivity of breastfeeding evaluation of premature infants is common practice in the clinical scenario of the Neonatal Intensive Care Unit by experienced speech-language pathologists (SLPs). They are used for the evaluation of breastfeeding, as those adapted for premature babies (Melo, 2008; Sanches, 2000). These require the use of products (equipment) to perform the exam, which despite being invasive techniques, they are commonly used in children using bottles (Anéas \& Dantas, 2014). Digital cervical auscultation is a noninvasive method. It is painless, without radiation exposure, and it is possible to apply it to the breast (Lagos et al., 2013). This method adds to the clinical evaluation, converting the muscle activity into auditory and/or visual stimulus.

Sonar Doppler was described as a means of acoustic analysis of swallowing sounds by Santos and Macedo (Santos \& Macedo Filho, 2006). The ease of adaptation of the method in premature infants enables quantitative assessment in the breast, without interfering with the physiological process of breastfeeding during sound measurement. This may be a complementary method for clinical evaluation.

Currently, there are no standard assessments that specify the correct time to initiate the transition from tube feeding to oral feeding, nor other specific forms of assessing premature infants (Lima et al., 2015). Therefore, the purpose of this study is to evaluate the feasibility of using swallowing acoustic analysis as an auxiliary method for the transition from nasogastric or orogastric tube to oral route. 


\section{Methodology}

Observational cross-sectional study. Approved by the Ethics Committee of the institution of origin, under the number 004518/2016.

Patients were selected from the Intensive Care Unit of XXX Hospital. The control group consisted of 16 full-term newborns, with an average gestational age of 39 to 70 weeks, with a minimum gestational age of 38.64 and a maximum of 41 weeks. The average weight of the full-term newborns was $3308.44 \mathrm{~g}$, with a standard deviation of $582.34 \mathrm{~g}$.

Inclusion criteria were: neonates admitted to the Neonatal Intensive Care Unit and the Intermediate Care Unit, clinically stable with corrected gestational age less than or equal to 36 weeks and six days. The control group considered newborn infants who were hospitalized in the maternity, breastfeeding on demand and with corrected gestational age greater than or equal to 38 weeks. Exclusion criteria included infants with craniofacial deformity, cardiovascular disorders, gastrointestinal disorders, neurological disorders, or other syndromes that impeded or made oral feeding difficult.

The newborns underwent the evaluation process, which included: The collection of identification and clinical data, speechlanguage pathology clinical evaluation, and swallowing sounds assessment by Sonar Doppler.

All evaluation procedures were performed and analyzed by the researcher. Data collection was taken from the hospital's electronic medical records. The instrument to assess the readiness of the premature infant to start oral feeding for clinical evaluation was subsequently used (Fujinaga et al., 2013). After the completion of the application protocol, the swallowing sound data were collected.

The preterm infants' swallowing sounds were captured during breastfeeding prior to commencing an oral diet. The mother was instructed to offer the breast normally, in the most comfortable position, keeping her neck free for transducer access. Infants with difficulty achieving the correct grip of the nipple received support from the therapist (help with positioning the newborn over the breast).

The Sonar Doppler transducer was positioned in the lateral region of the neck (right or left, depending on the breast the mother was breastfeeding from), on the lateral edge of the trachea and just below the cricoid cartilage, characterized as the best site for cervical auscultation by Takahashi et al. (1994).

The swallowing study was performed with a portable Sonar Doppler (model DF-4001, Martec brand) and a continuous flat disk transducer. The device operates on two batteries and features individual transducer, and a headphone, recorder, and computer output. The frequency of the Doppler ultrasound is $2.5 \mathrm{MHz}$, with an output of $10 \mathrm{~mW} / \mathrm{cm}^{2}$. The sound output power is $1 \mathrm{~W}$.

The continuous Doppler equipment was paired to an HP Pavilion standard notebook, model g4-1115br. The DeglutiSom® software, developed by Engefono (2014), was used to record, and analyze the acoustic signals. The referred software used in this study, was proved as having $97.0 \%$ sensitivity and $91.0 \%$ specificity according to previous studies (Silva et al., 2021).

The volume of the Doppler equipment was adjusted for the best acoustic signal pickup and the lowest external noise interference, with three minutes of captured signal. One minute of acoustic signal was selected for the analysis.

The study used descriptive (mean, standard deviation) and inferential (significance test) statistical analysis techniques. Spearman's correlation coefficient and Student's t-test were used. The significance level adopted was 0.05 (5\%).

\section{Results}

Fifty babies were selected, 32 of which met the eligibility criteria and completed the study. Among the patients who began the study during the evaluation period, there was $100 \%$ compliance with no casualties. 
Within the study group, the correlation between the score of the premature infant's readiness assessment instrument and the frequency, intensity, mean wave time, swallows per minute and time between swallows, showed significant results $(p=0.0216)$ for the intensity variable correlated with the assessment score. A significant correlation was also found between weight and frequency of the swallowing sound wave.

Within the control group, the distribution of the number of swallows per minute $(\mathrm{p}=0.0247)$ and the time between swallows $(\mathrm{p}=0.0320)$ presented a significant correlation with the premature infant's oral intake readiness assessment score (Fujinaga et al., 2013).

A significant correlation of variables was found for the study group $(\mathrm{p}=0.0152)$ and the control group $(\mathrm{p}=0.0007)$ when comparing the correlation between swallows per minute and time between the swallows (Table 1).

Table 1 - Correlation between swallows per minute, and time between swallows.

\begin{tabular}{l|c|c|c}
\hline \multicolumn{1}{c|}{ GROUPS } & N & CORRELATION OF SPEARMAN - & R \\
\hline Study Group (SG) & 16 & $-0,5941$ & $* 0,0152$ \\
Control Group (CG) & 16 & $-0,7572$ & $* 0,0007$ \\
\hline
\end{tabular}

Source: Authors.

A significant difference was found between the group mean values of the study group and the control group. The mean wave time variable for the study group was $37.87 \mathrm{~s}$, with a standard deviation of $33.65 \mathrm{~s}$. The mean for the control group was $6.08 \mathrm{~s}$ with a standard deviation of $18.93 \mathrm{~s}$, which was statistically significant $(\mathrm{p}=0.0025)$ (Table 2$)$.

Table 2 - Comparison between variables: frequency, intensity, average wave time, swallows per minute, time between swallows, scores, age, and weight.

\begin{tabular}{|c|c|c|c|c|c|c|c|}
\hline \multirow[b]{2}{*}{ VARIABLES } & \multicolumn{3}{|c|}{ STUDY GROUP (SG) } & \multicolumn{3}{|c|}{ CONTROL GROUP (CG) } & \multirow[b]{2}{*}{$\mathrm{P}$} \\
\hline & $\mathrm{N}$ & Average & $\begin{array}{l}\text { Standard } \\
\text { Desviation }\end{array}$ & $\mathrm{N}$ & Average & $\begin{array}{c}\text { Standard } \\
\text { Desviation }\end{array}$ & \\
\hline Frequency & 16 & 786,38 & 100,35 & 16 & 755,94 & 80,91 & 0,3524 \\
\hline Intensity & 16 & 68,38 & 34,66 & 16 & 87,48 & 23,02 & 0,0762 \\
\hline Average Wave Time & 16 & 37,87 & 33,65 & 16 & 6,08 & 18,93 & $* 0,0025$ \\
\hline $\begin{array}{l}\text { Swallows per } \\
\text { minute }\end{array}$ & 16 & 19,13 & 10,24 & 16 & 10,00 & 7,19 & $* 0,0066$ \\
\hline $\begin{array}{l}\text { Time between } \\
\text { Swallows }\end{array}$ & 16 & 9,54 & 19,34 & 16 & 7,64 & 3,71 & 0,7020 \\
\hline Score & 16 & 34,00 & 3,18 & 16 & 35,31 & 1,96 & 0,1703 \\
\hline
\end{tabular}

Source: Authors.

Swallowing per minute for the study group had a mean of 19.13 with a standard deviation of 10.24 . The mean result for the control group was 10.00, with a standard deviation of 7.19. Thus, the means presented significant differences $(\mathrm{p}=0.0066)($ Table 2$)$.

\section{Discussion}

The literature brings that many pathologies can cause dysphagia, such as temporomandibular disorder, and many other health conditions (Castilho et al., 2021). Furthermore, this symptom can affect different ages, depending only on its cause. So, in 
babies, dysphagia can be caused by many reasons, and it appears in the breastfeeding process, when the newborn and its mother, start to find difficulties on this activity.

During birth, premature and low birth weight infants may present with factors that influence breastfeeding behavior, delaying oral feeding (Esteves et al., 2014). An APGAR score below eight in the first and fifth minute is considered a risk factor for delayed initiation of breastfeeding (Marewood et al., 2006). In this study, all evaluated infants presented with a final APGAR score greater than eight in the fifth minute.

The infants who presented with higher scores in the oral feeding readiness assessment instrument also presented with a higher swallowing wave intensity value in the correlation of the variables in the study group.

As weight was gained, premature infants had decreased wave frequencies during breastfeeding. Vargas and colleagues ${ }^{12}$ evaluated the premature newborn's oral ability level and its relationship with oral feeding performance and growth. In this study, premature infants tended to have low weight and low oral skills. When oral intake was introduced, the infants presented with higher weight and higher oral skills (Vargas et al., 2015). Some studies also discuss the difficulty of premature infants with low weight in receiving intake exclusively by mouth. Many conditions were crucial in the evolution of the feeding conditions of this population, as showed in the literature (Medeiros et al., 2011; Scochi et al., 2010). These conditions included weight, the proposed assessment score, and overall clinical stability for the transition from the enteral tube to the breast.

The full-term newborns who had a higher number of swallows for one minute had an equally higher score on the pre-term oral feeding readiness assessment instrument proposed by Fujinaga and authors (Fujinaga et al., 2013), in the group correlation. Infants who had longer pause times between swallows, on the other hand, obtained lower scores in the assessment instrument (Fujinaga et al., 2013).

These results did not corroborate Silva's findings, which looked at the outcomes between the preterm and full-term newborn groups. During breastfeeding and bottle-feeding (premature infants were bottle-fed and full-term infants were breast-fed), the time involved for sucking/swallowing was longer in premature infants, albeit, the number of respiratory pauses was higher in the fullterm newborns (Vargas et al., 2015).

Considering that this sample evaluated both groups during breastfeeding, the neuromuscular development presented by the full-term newborns directly influenced breastfeeding performance (Yamamoto et al., 2009).

Significant results were observed for both groups when correlating swallowing per minute and time between swallows: All infants had a higher number of swallows and shorter pause time. The control group showed a higher correlation than the study group. It is understood that infants born full-term have a greater number of swallows to capture more breast milk during sucking, as they present with greater neuromuscular development and sucking/swallowing/breathing coordination with a lesser need for pause/rest.

On the other hand, premature infants, typically present with an immature sensorimotor-oral system, muscular hypotonia, short alert periods, large volume of milk in the oral cavity, and suction-swallowing-breathing incoordination. Any or all these conditions may have influenced the results of this study in premature newborns (Lima et al., 2015).

The preterm baby's mean time swallowing wave is longer than that of the full-term newborn. This significant difference did not influence the quality of breastfeeding presented by the study group. No evidence of laryngeal aspiration was presented, in the form of clinical signs or acoustic analysis by wave extension.

Premature infants presented with more swallows than the full-term newborns, according to the figures below. Silva reported that premature infants may have small suction bursts preceded or followed by swallowing, as well as prolonged suction bursts with multiple swallows, depending on their development (Figures 1 and 2) (Silva, 1999; Yamamoto et al., 2009). 
Figure 1 - Image of the swallowing sounds of the premature baby during breastfeeding.



Source: Authors.

Figure 2 - Image of the swallowing sounds of the full-term baby during breastfeeding.

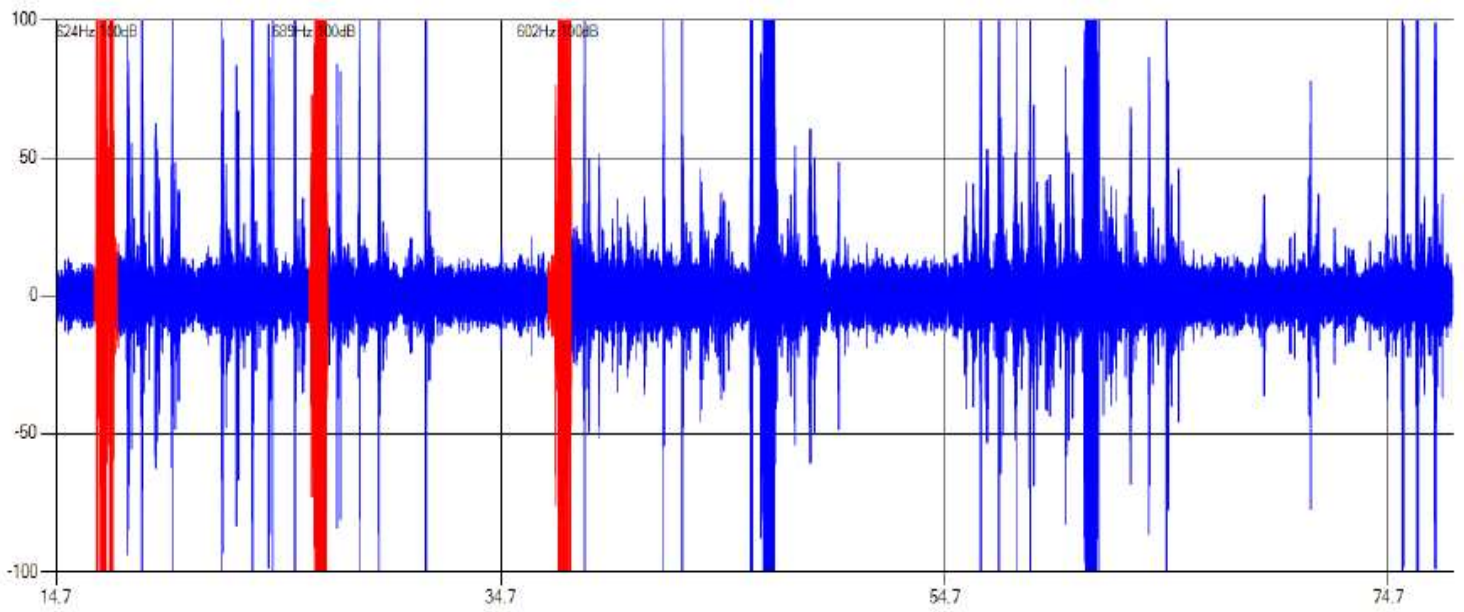

Source: Authors.

Acoustic analysis studies using other microphone assessment methods have evaluated premature and full-term infants during breastfeeding, concluding that premature infants have longer sucking/swallowing times and full-term infants have a greater number of breathing pauses during breastfeeding. the breastfeeding (Enz et al., 2021).

In a literature review, only one article was found using Sonar Doppler for the evaluation of premature and full-term infants. Lagos and colleagues conducted a study on both populations to characterize the swallowing sounds. In this study, the authors used breastfeeding and bottle-feeding. The difficulty of comparing the studies is due to the different analysis of the variables obtained by Sonar Doppler and a differentiated methodology (Lagos et al., 2013).

This study is the first of its kind looking at premature patients fed exclusively via the nasoenteral tube using Sonar Doppler and clinical evaluation of breastfeeding. 


\section{Conclusion}

The mean parameters found to initiate nasoenteral tube weaning in premature infants were: $786.38 \mathrm{~Hz}$ wavelength, 68.38 $\mathrm{dB}$ wavelength, 37.87s average wavelength, with an average of 19.13 swallows in one minute and a 9.54s pause between swallows.

The Sonar Doppler, as a sound capturing instrument, proved to be a viable auxiliary resource to evaluate the transition from nasogastric or orogastric tube feeding to oral feeding. The method did not interfere with the baby's breastfeeding pattern, as it was possible to apply it to the mother's breast. Moreover, it was noninvasive, painless, with no radiation exposure, and easy to apply and access.

It's important to emphasize the need of further studies to build a larger data base about the effective use of the acoustic analysis of swallowing sounds with the use of sonar doppler in premature babies during food transition.

\section{References}

Anéas, G. C. G, \& Dantas, R. O. (2014). A videofluoroscopia da deglutição na investigação da disfagia oral e orofaríngea. GE J Port Gastrenterol. 21(1):21-5.

Castilho, K. R. S., Cavalcante-Leão, B., Figueiredo, A. C. G. de., Ravazzi, G. M. C., Zeigelboim, B. S., Hummig, W., Santos, R. S., \& Stechman-Neto, J. (2021). Evaluation of swallowing pattern sound in patients with temporomandibular disorder. Research, Society and Development, 10(14), e403101421835. https://doi.org/10.33448/rsd-v10i14.21835

Enz, V. C. Q., Vaz, A. R. C., Nunes, M. C. A., Rosa, M. O., Nunes, J. A., Marques, J. M., \& Santos, R. S. (2021). Accuracy of Acoustic Evaluation of Swallowing as a Diagnostic Method of Dysphagia in Individuals Affected by Stroke: Preliminary Analysis. Dysphagia https://doi.org/10.1007/s00455-021-10358-5

Esteves, T. M. B., Daumas, R. P., Oliveira, M. I. C., Andrade, C. A. F., \& Leite, I. C. (2014). Amamentação na primeira hora de vida. Rev Saúde Pública. 48(4): 697708 .

Fujinaga, C. I., Moraes, S. A., Zamberlan-Amorim, N. E., Castral, T. C., Silva, A. A., \& Scochi, C. G. S. (2013). Validação clínica do instrumento de avaliação da prontidão do prematuro para início da alimentação oral. Rev. Latino-Am. Enfermagem. 21(especial):

Hawdon, J. M., Beauregard, N., Slattery, J., \& Kennedy, G. (2000). Identification of neonates at risk of developing feeding problems in infancy. Dev Med Child Neurol. 42(4):235-9.

Klock, P. E., \& Alacoque, L. E. (2012). Caring for newborns in a NICU: dealing with the fragility of living/surviving in the light of complexity. Rev Esc Enferm USP. 46(1):43-9.

Lagos, H. N. C., Santos, R. S., Abdulmassih, E. M. S., Gallines, L. F., \& Langone, M. (2013). Characterization of swallowing sounds with the use of sonar doppler in full-term and preterm newborns. Int Arch Otorhinolaryngol. 17(4):383-6.

Lima, A. H., Côrtes, M. G., Bouzada, M. C., \& Friche, A. A. (2015). Preterm newborn readiness for oral feeding: systematic review and meta-analysis. CoDAS. 27(1): 101-7.

Marewood, A., Brooks, D., Bauchner, H., MacAuley, L., \& Mehta. S, D. (2006). Maternal birthplace and breastfeeding initiation among term and preterm infants: a statewide assessment for Massachusetts. Pediatrics. 118(4):e1048-54, 10.1542/peds.2005-2637.

Medeiros, A. M. C., Oliveira, A. R. M., Fernandes, A. M., Guardachoni, G. A. S., Aquino, J. P. S. P., Rubinick, M. L., Zveibil, N. M., \& Gabriel, T. C. F. (2011). Caracterização da técnica de transição da alimentação por sonda enteral para seio materno em recém-nascidos prematuros. Soc Bras Fonoaudiol. 23(1):57-65.

Melo, A. M. (2008). Avaliação da mamada em recém-nascidos prematuros [Dissertação]. Universidade Federal de Pernambuco.

Sanches, M. T. C. (2000). Dificuldades iniciais na amamentação: enfoque fonoaudiológico [Dissertação]. Faculdade de Saúde Pública da Universidade de São Paulo.

Santos, R. S., \& Macedo Filho, E. D. (2006). Sonar Doppler como instrumento de avaliação da deglutição. Arq. Int. Otorrinolaringol. 10(3):182-91.

Scochi, C. G. S., Gauy, J., Fujinaga, C. I., Fonseca, L. M. M., \& Zamberlan, N. E. (2010). Transição alimentar por via oral em prematuros de um Hospital Amigo da Criança. Acta Paul Enferm. 23(4):540-5.

Silva, C. S. (2013). Avaliação da coordenação sucção/deglutição/respiração através da ausculta cervical digital em recém-nascidos pré-termo e a termo [dissertação]. Porto Alegre (RS): Universidade Federal do Rio Grande do Sul;

Silva, R. N. M. (1999). Fatores que interferem na sucção/deglutição/respiração do prematuro. In: Lopes, J. M. A., \& Lopes, S. M. B. (orgs). Follow-up do recémnascido de alto risco. Rio de Janeiro: Medsi; 275-300.

Takahashi, K., Groher, M., \& Michi, K. (1999). Methodology for detectiong swallowing sounds. Dysphagia. 9(1):54-62. 
Research, Society and Development, v. 11, n. 1, e52811125262, 2022

(CC BY 4.0) | ISSN 2525-3409 | DOI: http://dx.doi.org/10.33448/rsd-v11i1.25262

Vargas, C. L., Berwig, L. C., Steidl, E. M. S., Prade, L. S., Bolzan, G., Keske-Soares, M., \& Weinmann, A. R. M. (2015). Premature: growth and its relation to oral skills. CoDAS. 27(4):378-83.

Yamamoto, R. C. C., Keske-Soares, M., \& Weinmann, A. R. M. (2009). Sucção nutritiva de recém-nascidos pré-termo. Rev Soc Bras Fonoaudiol. 14(1):98-105.

Silva, G. S., Figueiredo, A. C. G., Zeigelboim, B. S., Araújo, C. M., Stechmann-Neto, J., \& Santos, R. S. (2021). Acoustic analysis of swallowing as an auxiliary method for assessing dysphagia in Parkinson's disease. Research, Society and Development, 10(16), e323101623298. https://doi.org/10.33448/rsd-v10i16.23298. 